\title{
Tracheal Leiomyoma
}

National Cancer Institute

\section{Source}

National Cancer Institute. Tracheal Leiomyoma. NCI Thesaurus. Code C6049.

A benign smooth muscle neoplasm arising from the trachea. It is characterized by the presence of spindle cells with cigar-shaped nuclei, interlacing fascicles, and a whorled pattern. 